\title{
本州中部亜高山帯の半自然草原におけるヤナギラン群 落の群落構造と立地環境
}

\author{
The Sructure and Habitat Conditions of Epilobium angustfolium Communities on Semi-natural Grassland in \\ the Sub-alpine Zone of Middle of Japan
}

\author{
森＼cjkstart有希* 大窪久美子** \\ Yuki MORI Kumiko OKUBO
}

\begin{abstract}
The purpose of this study was to clarify the structure and habitat conditions of Epilobium angustfolium communities for the sake of vegetation management on semi-natural grassland. Vegetation and soil conditions of Epilobium angustfolium communities were investigated at four study areas in the middle-southern part of Nagano Prefecture in central Japan. Five types of plant communities were distinguished at the third level of the TWINSPAN classification, and at the fourth level, seven variations of one were distinguished. These vegetation types were related in various study areas. Epilobium angustfolium communities were formed at from man-made naked lands to Miscanthus sinensis type grasslands. Except for one type of Epilobium angustfolium community, all vegetation types were consisted of many characteristic species of Arundinello-Miscathion sinensis alliance. The DCA axis 1 was related to the species diversity and gradient of the communities, on the other hand the DCA axis 2 was related to the soil moisture on the ones. It suggested that the habitat niche of Epilobium angustfolium is remarkably wide
\end{abstract}

Keywords: semi-natural grassland, Epilobium angustifolium, community structure, habitat condition キーワード : 半自然草原, ヤナギラン, 群落構造, 立地環境

\section{1.はじめに}

ヤナギラン (Epilobium angustifolium L.) は夏緑広葉樹林 から亜高山帯針葉樹林域の下限に分布するアカバナ科の多年生植 物で, 長野県では, 標高約 $900 \sim 2100 \mathrm{~m}^{1}{ }^{1}$ に生育することが報告 されている。本種は森林伐採後など破壊された森林跡に成立する 切り跡群落の代表構成種といわれ2), 北米では火事跡地で優占す る種として知られている ${ }^{3)}$ 。しかし長野県に扔いてヤナギラン群 落は, 刈り取りや放牧, 火入れなどの人為的管理によって維持さ れてきた半自然草原としても成立している。このような半自然草 原としてのヤナギラン群落やその種生態に関する既存の研究は少 ない。

一方, ヤナギランは紅紫色の鮮やかな花色と群生する特性から, 夏季の高茎草原景観を形成する点において優れている。スキー場 や道路法面緑化に打いて外来植物の利用が問題となる中, 在来種 であるヤナギラン群落の成立や個体群維持を可能とする植生管理 方法が明らかになれば, 景観資源の面からみても, その意義は大 きい。特に既に外来植物による緑化工が施工されたスキー場法面 においては, 土袞侵食防止の面からあ在来種による植生に推移さ せていくことが重要であり ${ }^{4)}$, ヤナギラン等の高茎草原群落の有 用性は高い。

そこで本研究では, ヤナギラン群落の成立及び維持のための植 生管理に関する基礎的知見を得るため, 長野県中南部亜高山帯に おける本群落の組成及び群落構造, 立地環境を明らかにし, 管理 状況との関係性を考察することを目的とした。なお, 長野県内の ヤナギランをウスゲヤナギランとする見解 ${ }^{1)}$ あるが，本論文で はより一般的見解として, すべての標本同定をヤナギランとして 扱った。

\section{2. 調查地域}

調査地域は長野県中南部の入笠山 $(1955 \mathrm{~m})$, 八子ヶ峰（1833 m), 高ボッチ山 $(1664 \mathrm{~m})$ 及び池山 $(1774 \mathrm{~m})$ の中腹, 標高
1500 1800mに位置する 4 つの半自然草原に設定した。聞き取り 調查結果から各調查地域の半自然草原の管理状況を以下にまとめ た。入笠山はカラマッ林に囲まれた小規模草原であり, 1970 年 代より草原景観維持のため, 年 1 回秋の草刈りが行なわれている 他, 一部分の草原では山小屋管理者による選択的な刈り取りも随 時行なわれてきた。八子ヶ峰は周辺の大規模草原と連続し, 稜線 部を除いて冬期はスキー場として利用されており，1980 年代よ り年 1 回秋の草刈りが行なわれている。高ボッチ山では本調查地 内では特に管理は行われていなかったが, 過去には刈り取り管理 が行われていたと考えられた。池山に扔いては, 地元有志らによ るヤナギラン群落維持のための刚り取り管理が 1990 年より年 2 回春之秋に行なわれている。対象地の地質は, 入笠山が四万十累 带, 八子ヶ峰, 高ボッチ山が第四紀火山岩類, 池山が領家花崗岩 類 ${ }^{1)}$ である。長野県の中信高原を代表する霧ヶ峰車山（1925m） の年平均気温は $2.5^{\circ} \mathrm{C}$, 年降水量は $1855 \mathrm{~mm}^{5)}$ であり, 本デー夕か ら 4 調査地の年平均気温を換算すると $3.1 \sim 4.8^{\circ} \mathrm{C}$ (莪減率 -0.55 ${ }^{\circ} \mathrm{C} / 100 \mathrm{~m}$ ）の範囲となる。また車山湿原（1780m）に打ける WI は 44.5 月・ ${ }^{\circ} \mathrm{C}, \mathrm{CI}$ は -46.2 月・ ${ }^{\circ} \mathrm{C}^{6)}$ でトウヒーコケモモクラス 域に含まれる。

\section{3. 調查方法 \\ (1) 植生調査}

入笠山, 八子ヶ峰及び池山については 2002 年 $8 \sim 9$ 月, 高ボッ チ山については 2003 年 8 月に, それぞれヤナギランが生育する 群落を中心に, 計 184 個のプロット $(2 \mathrm{~m} \times 2 \mathrm{~m})$ を設定し, 全 出現種の被度, 群度, 植物高を測定した。

\section{（2）立地環境調査}

植生調査と同時にプロットの傾斜, 斜面方位, 植被率を測定し た。また土壤含水率は, 各年 9 月に, Campbell 社 Hydrosense （似 TDR 式）を用いて, 各プロット内で 9 箇所ランダムに測定 し, その平均值を求めた。

*信州大学大学院農学研究科 ${ }^{* *}$ 信州大学農学部 


\section{4. 結果}

\section{(1) TWINSPAN 解析}

全出現種は 225 種であった。被度百分率と植物高より相対積算 優占度 $\left(\mathrm{SDR}_{2}{ }^{\prime}\right)^{7)}$ を算出し, TWINSPAN 解析 ${ }^{8)}$ を行った。Cut level は 0.0，2.0，5.0，10.0，20.0 の規定值を用いた。

群落デー夕は第 3 分割までで 5 型が，さらに第 4 分割で 7 型に 分類された（図一 1 )。第 1 分割ではイタドリ，アオスゲ，ミヤ コザサ及びミッバッチグリ，ミヤマニガイチゴによって， E 型 （池山）とその他に分かれた。

第 2 分割では，ハクサンフウロ，チゴユリ，ナットウダイ， ワ レモコウを指標種として A 型（八子ヶ峰中部）と B 型（八子ヶ 峰上部，稜線部）, $\mathrm{C}$ 型 (入笠山, 高ボッチ山等) と D 型（八子 ヶ峰下部) に, 第 3 分割では, オカトラノオ, オニッルウメモド キ,コウシンャマハッカを指標種として A 型と B 型が分かれた。

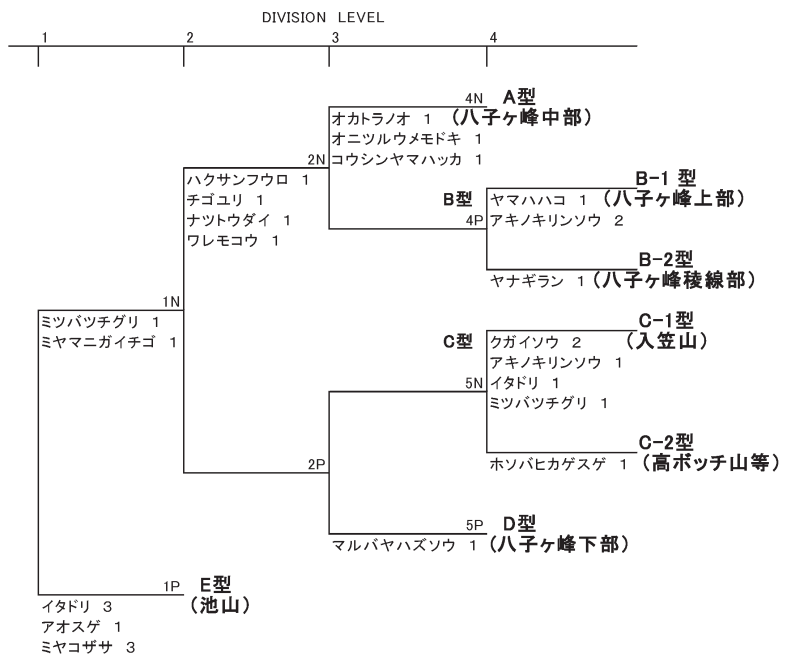

図－1 全調査区の TWINSPAN 解析結果のデンドログラム 注) 種名 indicator species $\mathrm{N}$ :Negative group $\mathrm{P}:$ Positive group cut level:0.0,2.0,5.0,10.0,20.0
同じくマルバヤハズソウを指標種として D 型と C 型が分かれた。 さらに第 4 分割において，B型はヤマハ八コ，アキノキリンソ ウを指標種として B-1 型（八子ヶ峰上部）とヤナギランを指標 種として B-2 型（八子ヶ峰稜線部）に，C型はクガイソウ，アキ ノキリンソウ，イタドリ，ミッバッイチグリ及びホソバヒカゲス ゲを指標種として C-1 型（入笠山）と C-2 型（高ボッチ山等） に分かれた。

これらの結果, 調査群落は大きく A,B,C,D,Eの 5 群落型に分 類された。そのうち $\mathrm{B}, \mathrm{C}$ の 2 群落において， 2 つの亜群落型に 分類された。群落型は，主に調査地の違いに対応していた。

\section{(2) 種群}

TWINSPAN の種群の分類より，5群落型の出現種について, 模式図を作成した（図一-2)。ただし，出現頻度 $3 \%$ 以下の種は 省略した。5 群落型の共通種群（I 群）では，ヤナギラン（出現 頻度 79.9\%）の他，出現頻度 30\%以上の種としては，ススキ, ヨッバヒヨドリなどのトダシバーススキ群団の標徴種 $\left.{ }^{9}\right)$ や，ヒメ シダ，ホソバヒカゲスゲ，オオヤマフスマ，イタドリ，ワラビ, ヨモギなどの多年生草本植物, 木本植物のレンゲッッジ等が認め られた。E 型以外での群落型の共通種群（II型）としては，ミヤ マニガイチゴやスズラン，クガイソウなどの他，ミッバッチグリ， ッリガネニンジン，ワレモコウ，カワラマッバ，ノコンギク，， アザミ，アキカラマッ，チダケサシなど計 15 種のトダシバース スキ群団の標徵種が認められた。また A,B 型に出現が偏るもの の, タチッボスミレ，オトギリソウについても，同様であり， II 群に分類された種の $43.75 \%$ がトダシバーススキ群団の標徵種で あった。またこれら出現した標徴種のほとんどは多年生草本であった。 各群落型の特徵として，B 型では，上記に加えて二ガナ，スミ レ，ウッボグサ，リンドウ等（林群）のトダシバーススキ群団の 標徵種が多く出現した。 $\mathrm{C}$ 型では，木本植物のズミやシラカンバ, ミヤママタタビ，ミヤマイボタ，ユモトマユミ，イボタノキと, 亜高山帯針葉樹林の林床植物であるマイッ゙ルソウやべニバナイチ ヤクソウが，D型では緑化材に用いられるマルバヤハズソウや シロッメクサが構成種として認められた。 $\mathrm{E}$ 型はミヤコザサ等の IV 群の出現と, II 群のトダシバーススキ群団の標徵種を欠くこと で特徴づけられた。

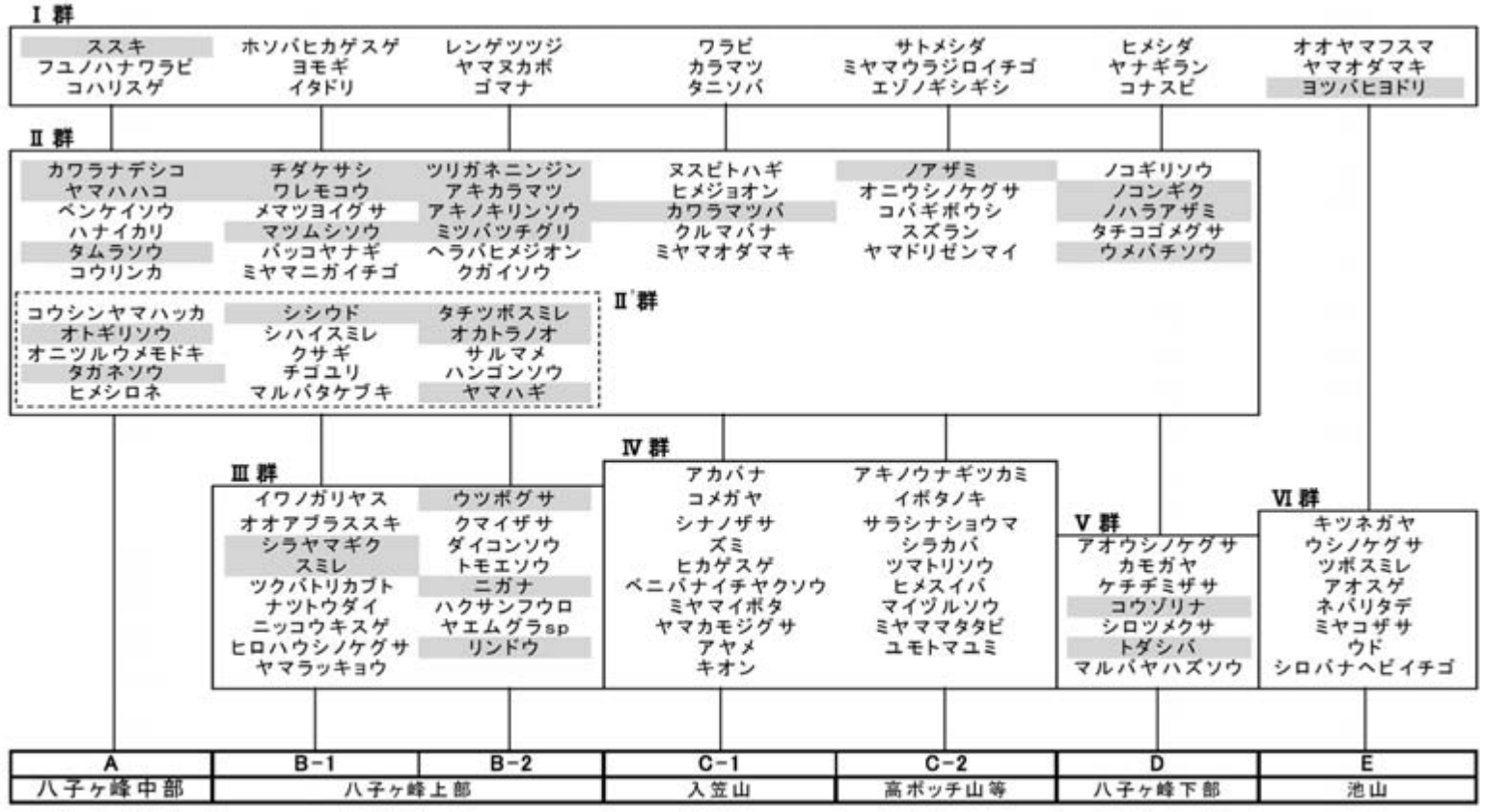

図－2 TWINSPAN 解析による種群分類の模式図（出現頻度 $3 \%$ 以下は省略）

はトダシバーススキ群団の標徽種 

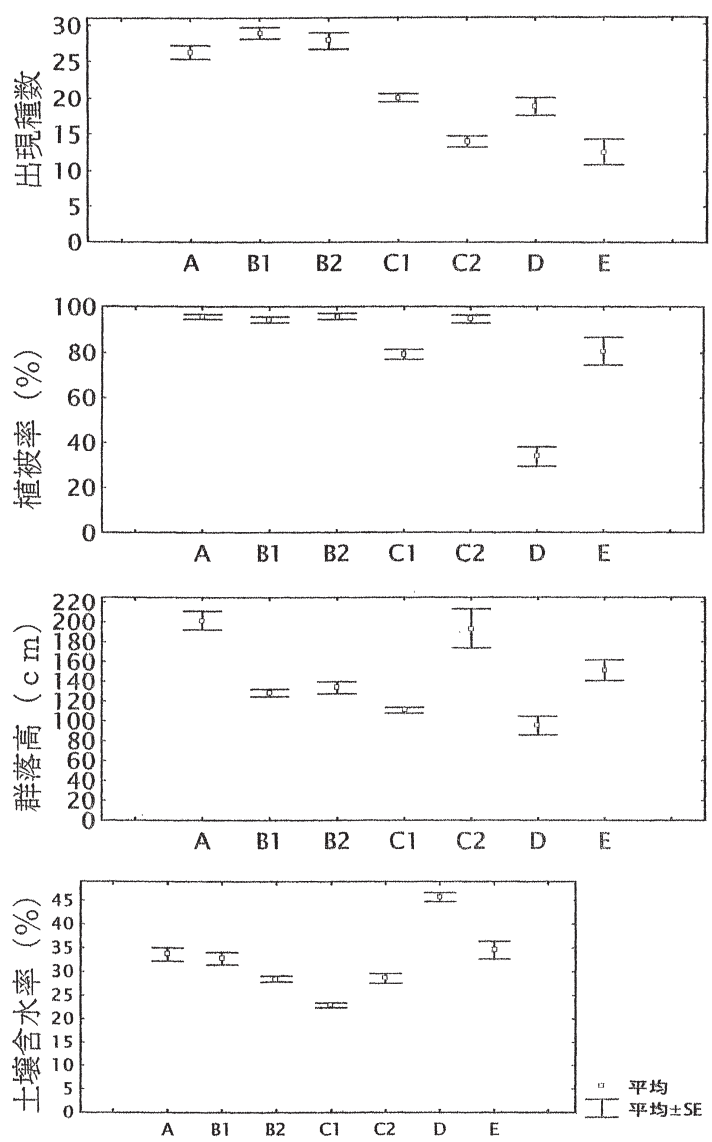

図-3 各群落型の出現種数・植被率・群落高・土壤含水率

（3）出現種数・植被率・群落高・土壤含水率

TWINSPAN 解析で得られた各群落型の出現種数, 植被率, 群落高, 土㳖含水率を図一 3 に示した。また群落型間の比較をシェ フェの多重比較検定によって行った（表一 1 ）。出現種数は, $\mathrm{A}, \mathrm{B}$ 型がそれぞれ C,D,E 型より， C-1 型が C-2,E 型より有意に 多かった（p<0.05）（図-3）。植被率は， C-1 型が A,B,C-2 型 より，D型がその他より有意に低かった。群落高は， $\mathrm{A}$ 型が B,C-1,D 型より，C-2 型が B,C-1,D 型より高かった。土㙥含水率 は，C-1 型がその他より，C-2 型が $\mathrm{E}$ 型より有意に少なく，D型 がその他より有意に高かった。

\section{(4) DCA 序列化}

DCA 序列化法 ${ }^{10)}$ は反復平均法を改良した序列化方法で群落の 組成的な变化々環境要因との対応関係をみるものである。全調査 区を各種の相対積算優占度を用いて, DCA 序列化法によって分 析した（図-4）。表一 2 には DCA 各軸のスコアと環境条件と の相関関係を示した。第 I 軸（固有值 0.555）では，各群落型は B-1 型, $\mathrm{A}$ 型・B-2 型・D 型, C-1 型, C-2 型, $\mathrm{E}$ 型の順に左から右に 配列された。第 I 軸は群落の傾斜度で正の, 出現種数で負の有意 な相関がみられ $(\mathrm{p}<0.05)$, 左から右に傾斜度が高くなるととも に群落の多様性が低下することを示す軸として考えられた。第 II 軸（固有值 0.483）では, 各群落型は C-1 型, C-2 型・B-2 型, B-1 型， $\mathrm{A}$ 型， $\mathrm{E}$ 型， D 型の順に下から上に配列された。第 II 軸 は土壤含水率で正の, 出現種数と植被率で負の有意な相関がみら れた（ $<<0.05 ）$ 。下から上に土㙵含水率が高くなる環境傾度を示 す軸として考えられた。

\section{5. 考察}

ヤナギラン生育地周辺の群落は主に 5 つの群落型に分類され, これらは調查地に対応した。各群落型の特徵については表一 3 に
表 -1 各群落型の出現種数・植被率 $\cdot$ 群落高・土壤水分の Scheffe 法による多重比較

\begin{tabular}{|c|c|c|c|c|c|c|c|c|}
\hline & 平均値 & $\mathrm{A}$ & B1 & B2 & $\mathrm{C} 1$ & $\mathrm{C} 2$ & D & $E$ \\
\hline A & 26.24 & $\bullet$ & 0.797 & 0.987 & $0.001^{* *}$ & $0.000^{2 * 2}$ & $0.042^{*}$ & $0.000^{2 k s}$ \\
\hline B1 & 28.85 & - & $\bullet$ & 0.996 & $0.000^{* *}$ & $0.000^{* *}$ & $0.000^{* *}$ & $0.000^{* *}$ \\
\hline B2 & 27.76 & - & - & $\bullet$ & $0.000^{* *}$ & $0.000^{* * *}$ & $0.003^{* *}$ & $0.000^{* *}$ \\
\hline $\mathrm{C} 1$ & 19. 99 & - & - & - & $\bullet$ & $0.000^{* *}$ & 0.998 & $0.000^{* *}$ \\
\hline $\mathrm{C} 2$ & 14. 04 & - & - & - & - & $\bullet$ & 0.417 & 0.989 \\
\hline D & 18.75 & - & - & - & - & - & $\bullet$ & 0.179 \\
\hline E & 12.67 & - & - & - & - & - & - & $\bullet$ \\
\hline \multicolumn{9}{|c|}{ 植被率 } \\
\hline & 均値 (\%) & $\mathrm{A}$ & B1 & B2 & $\mathrm{C} 1$ & $\mathrm{C} 2$ & D & $E$ \\
\hline A & 95.65 & $\bullet$ & 1.000 & 1.000 & $0.015^{*}$ & 1.000 & $0.000^{* * * *}$ & 0.192 \\
\hline B1 & 94.35 & - & $\bullet$ & 1. 000 & $0.006^{* *}$ & 1.000 & $0.000^{* *}$ & 0.185 \\
\hline B2 & 95.91 & - & - & $\bullet$ & $0.004^{* *}$ & 1.000 & $0.000^{* * *}$ & 0.127 \\
\hline $\mathrm{C} 1$ & 79.32 & - & - & - & $\bullet$ & $0.003^{* *}$ & $0.000^{* * *}$ & 1.000 \\
\hline $\mathrm{C} 2$ & 94.68 & - & - & - & - & $\bullet$ & $0.000^{* *}$ & 0.147 \\
\hline D & 33.75 & - & - & - & - & - & $\bullet$ & $0.000^{* * *}$ \\
\hline E & 80.72 & - & - & - & - & - & - & $\bullet$ \\
\hline \multicolumn{9}{|c|}{ 群落高 } \\
\hline & 均值 $(\mathrm{cm})$ & $\mathrm{A}$ & B1 & B2 & $\mathrm{C} 1$ & $\mathrm{C} 2$ & D & $E$ \\
\hline A & 201.18 & $\bullet$ & $0.001^{* * 4}$ & $0.007^{* *}$ & $0.000^{* *}$ & 0.999 & $0.000^{* *}$ & 0.160 \\
\hline B1 & 128.15 & - & $\bullet$ & 1. 000 & 0.870 & $0.001^{* *}$ & 0.819 & 0.875 \\
\hline B2 & 133.33 & - & - & $\bullet$ & 0.738 & $0.007^{* *}$ & 0.719 & 0.969 \\
\hline $\mathrm{C} 1$ & 110.59 & - & - & - & $\bullet$ & $0.000^{* *}$ & 0.993 & 0.130 \\
\hline $\mathrm{C} 2$ & 193.00 & - & - & - & - & $\bullet$ & $0.000^{* * *}$ & 0.229 \\
\hline D & 94.88 & - & - & - & - & - & $\bullet$ & 0.278 \\
\hline $\mathrm{E}$ & 151.22 & - & - & - & - & - & - & 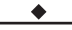 \\
\hline \multicolumn{9}{|c|}{ 土壤水分 } \\
\hline & 均値 (\%) & $\mathrm{A}$ & B1 & $\mathrm{B} 2$ & $\mathrm{C} 1$ & $\mathrm{C} 2$ & D & $E$ \\
\hline A & 33.64 & $\bullet$ & 1.000 & 0.197 & $0.000^{* *}$ & 0.162 & $0.000^{* *}$ & 1.000 \\
\hline B1 & 32.80 & - & $\bullet$ & 0.279 & $0.000^{* * *}$ & 0.226 & $0.000^{\text {ser }}$ & 0.976 \\
\hline B2 & 28.52 & - & - & $\bullet$ & $0.009^{* * *}$ & 1.000 & $0.000^{\text {*t* }}$ & 0.054 \\
\hline $\mathrm{C} 1$ & 22.90 & - & - & - & $\bullet$ & $0.002^{* *}$ & $0.000^{* *}$ & $0.000^{* *}$ \\
\hline $\mathrm{C} 2$ & 28.61 & - & - & - & - & $\bullet$ & $0.000^{* * *}$ & $0.038^{*}$ \\
\hline D & 45.72 & - & - & - & - & - & $\bullet$ & $0.001^{* *}$ \\
\hline E & 34.59 & - & - & - & - & - & - & $\bullet$ \\
\hline
\end{tabular}

まとめた。 $\mathrm{A}, \mathrm{B}$ 型（八子ヶ峰中部，上部）は出現種数が平均值 25 種以上と多く，植被率も平均值 $90 \%$ 以上之高い。これは調査地 域が隣接する霧ヶ峰や車山高原と連続する大規模な半自然草地で あり, 地域全体として亜高山带半自然草原の構成種が多く分布す る植物地理的要因が考えられた。高茎草原の構成種となるススキ一 トダシバ群団の標徵種が多く出現することからも，目標とすべき 在来の半自然草原として示唆された。A,B型では秋に年一回の 刈り取りが行われており，ヤナギランを含むこれらの群落型維持 には同等の管理が必要であることが示唆された。

それに対して，C-1型（入笠山）は亜高山帯針葉樹林の木本植 物や林床植物の種群IV群の出現によって特徵付けられるが，出現 種数は A,B 型より少なく, 植被率も低い。I 群とII群以外のト ダシバーススキ群団の標徵種を欠いており, 組成的には多様性が 低く評価された。これは前述のと抢り，草原がカラマッ林に囲ま れて面積的に小さいこと，また土㙵含水率が低く，乾燥化が影響 していることが考えられた。前述した年 1 回の刈り取りに加えた 選択的な刈り取り管理が多様性低下に与える影響む示唆された。

C-2 型（高ボッチ山と入笠山，八子ヶ峰の一部）は C-1 型と同 じく種群 I 群と II 群以外のトダシバーススキ群団の標徴種を欠い ており, IV 群の出現によって特徵づけられ, 出現種数は A,B,C-1 型より少なく, 多様性は低かった。高ボッチ山では群落の上層を 被覆する木本植物のズミの優占度が高く, これが光環境を低下さ せ，多様性を低下させる原因になっていると考えられた。ヤナギ ラン生育地や半自然草原維持のために，年一回の刈り取り管理が 必要であると考えられた。また他にC-2 型には，牧草由来之考 えられたオニウシノケグサが優占する調査区（入笠山）やミヤマ ウラジロイチゴの優占する調査区（八子ヶ峰）が含まれた。特定 の種が著しく優占するため, これが出現種数を減少させる要因の 一つであると考えられた。特定の種の優占は前者では牧草を用い た緑化工が，後者では偏向遷移に移行したことが原因である。こ れらの群落を $\mathrm{A}, \mathrm{B}$ 型へ移行させるためには, 在来種の種子供給 や，刈り取りを除く人為行為の停止など長期にわたる維持管理が 
表 -2 DCA 第 1 軸と第 2 軸の各スコアと環境条件の相関関係

\begin{tabular}{|c|c|c|c|c|c|c|c|}
\hline & DCA第1軸スコア & DCA第2軸スコア & 傾斜度 & 出現種数 & 植被率 & 群落高 & 土壤含水率 \\
\hline 傾斜度 & $0.20^{* *}$ & -0.06 & $\bullet$ & -0.03 & -0.06 & 0.13 & -0.14 \\
\hline 出現種数 & $-0.69^{* *}$ & $-0.47^{* *}$ & - & $\diamond$ & 0.08 & 0.00 & 0.03 \\
\hline 植被率 & -0.04 & $-0.29^{* *}$ & - & - & $\diamond$ & $0.43^{* *}$ & -0.05 \\
\hline 土壌含水率 & -0.04 & $0.40^{* *}$ & - & - & - & - & $\diamond$ \\
\hline
\end{tabular}

值はピアソンの積率相関係数。 $* *$ * $\mathrm{P}<0.01$

表 -3 各群落型の特徴

\begin{tabular}{|c|c|c|c|c|}
\hline 群落 & 多様 可 & 莑落 & 管理状況 & 種群の特徵 \\
\hline $\mathrm{A}$ & 高 & 高 & 秋年一回刘り取り & ススキートダシバ群団の標徴種の出現 \\
\hline B-1 & 高 & 低 & 秋年一回刈り取り & ススキートダシバ群団の標徴種の出現 \\
\hline $\mathrm{B}-2$ & 高 & 低 & 秋年一回刈り取り & ススキートダシバ群団の標徴種の出現 \\
\hline $\mathrm{C}-1$ & 中 & 低 & 秋年一回、選択的刈り取り & 亜高山帯針葉樹林の木本植物や林床植物の出現 \\
\hline $\mathrm{C}-2$ & 低 & 高 & 特になし & 木本植物の侵入、牧草由来のイネ科の優占 \\
\hline D & 中 & 低 & 秋年一回刈り取り & カモガヤ、シロツメクサなどの緑化材の出現 \\
\hline E & 低 & 中 & 春秋年二回刈り取り & ミヤコザサの優占 \\
\hline
\end{tabular}

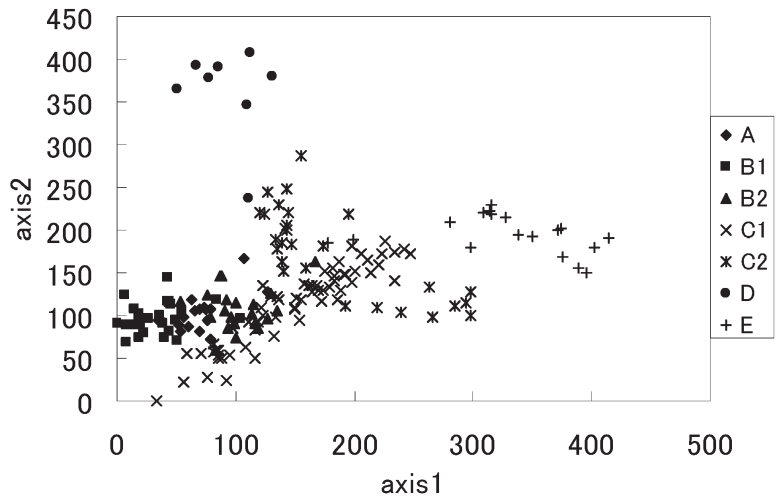

図－4ＤCA 序列化法による各群落型の序列づけ

必要であると考えられた。

また， A,B 型と同じ八子ヶ峰に成立する D 型は, 組成として 種群 II'群之 III 群を欠き，緑化材に用いられるカモガヤ，シロッ メクサやマルバヤハズソウ等の V 群の出現で特徵づけられた。 $\mathrm{D}$ 型はスキー場内リフト下の人工裸地の群落で, 出現種数が少なく, また植被率は低く, 粘土質土壤のため土壤含水率が高かった。ヤ ナギランは生育しているあのの, 著しい矮化個体群で, これは土 壤条件に因るむのであると考えられ，種組成からあ成立目標には 適さない群落型であると評価された。ヤナギランは, 森林土壌に 成立する $\mathrm{A}, \mathrm{B}$ 型から粘土土壤の造成裸地に成立する $\mathrm{D}$ 型まで個 体群を形成することから, 本種の生育ニッチの幅は広いことが示 唆された。またりフト造成時やスキー場としての利用による人為 攪乱が大きいと考えられ，緑化材として使われた外来植物の侵入， 定着が問題であり, 同じ人為が働けば, A,B 型の半自然草原に 移行することは難しいと考えられた。

池山の $\mathrm{E}$ 型は半自然草原の面積が小規模で, 周囲にシードソー スとなる草原植生のないことが, 全体的に出現種数が少ない要因 と考えられた。また, 刈り取り管理の回数が年 2 回之他の調查地 よりも多く, 春に刈り取ること, ヤナギランなどの多年生草本の 競合種であるミヤコザサの優占度の高い区が存在することも, 出 現種数の減少に影響すると考えられた。

既存の植物社会学的研究ではヨツバヒヨドリ一ヤナギラン群 集 $^{8)}$ は山地高荃広葉草原としてオニシモッヶーオオヨモギクラス に位置付けられており, ヤナギランを標徵種，ワラビ， シモッケ， ミヤマナルコユリなどを区分種としている。その構成種には，ヨ

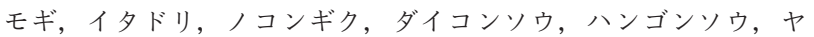
マドリゼンマイ, ウドなど本研究で出現が確認された種が多くあ げられている。したがって, 今回得られたヤナギラン群落も基本 的にはヨッバヒヨドリ一ヤナギラン群集に含まれると考えられた。
しかし本研究の結果，ヤナギランの生育する群落は，刈り取りな どの維持管理を受けることによって構成種にトダシバーススキ群 団の標徵種を多数含む多様性の高い群落型から木本植物が優占す る群落型や偏向遷移が進行している群落型まで多くの群落型の存 在することが明らかになった。各群落型は周辺植生との関係性や 草原の地理的条件，土壤水分条件，管理条件之密接に関係するこ とが示唆された。また一方で, 本調査からヤナギランは人工裸地 加 ススキ型草地までの幅広いニッチに生育する種特性を有する ことが明らかになった。

ヤナギラン群落の植生管理については, 群落の成立や維持のた めには, 競合種である木本植物及びササ類を抑制するための刈り 取り管理等が必須であると考えられるが，具体的な管理の頻度や 時期については対象地ごとに群落の現状を把握し, 検討しなけれ ばならない。また植物地理的背景や周囲の植生環境が異なれば, 同様の管理を他地域で行ったとしても，誘導される群落型は異な り，管理目標を検討する場合には，これらの条件を考慮に入れ， 目標群落を設定する必要性のあることが指摘された。

さらに外来植物を用いた緑化工によりこれらの植物種が定着し た群落型や偏向遷移が進行した群落型をヤナギランなどの在来半 自然草原に移行していく手法の確立むこれからの課題である。

\section{引用・参考文献}

1) 長野県植物誌編纂委員会（1997）：長野県植物誌：信濃毎日新聞社, $1735 \mathrm{pp}$

2 ）宮脇昭編（1977）：日本の植生：学習研究社, $272 p p$

3 ）津田智（1991）: 火と植物群落（ファイアーエコロジー, 飯泉茂編著）: 東海大学出版会, 192pp

4 ）露崎史朗（1991）：北海道におけるスキー場植生の現状と推移一地表 改变・播種により造成維持されている場合一：日本生態学会誌 41(2), $83-91$

5 ）松田行雄・土田勝義（1985）：美ヶ原・霧ヶ峰の植物：信濃毎日新聞, 263pp

6 ）諏訪市教育委員会（1981）：霧ヶ峰の植物：諏訪市教育委員会,18pp

7 ) 沼田眞（1965）：草地の状態診断に関する研究 II 一種類組成による診 断：日本草地学会誌 $12(1), 29-36$

8 ) Hill, M. O. (1979) : TWINSPAN - A FORMAN program for arranging multivariate data in an ordered two-way table by classification of the individuals and attributes : Cornell University Press, $99 \mathrm{pp}$

9 ）宮脇昭（1985）：日本植生誌中部：至文堂, 604pp

10) Hill, M.O. and Gauch, H.G. (1980): Detrended correspondence analysis, an improved ordination technique : Vegetatio 42, 45-58 